\title{
Finite vs. non-finite complementation in Post-classical and Early Byzantine Greek
}

\section{Towards a pragmatic restructuring of the complementation system?}

\author{
Klaas Bentein* \\ Ghent University \\ klaas.bentein@ugent.be
}

\begin{abstract}
While Classical Greek has a particularly rich complementation system, in later times there is a tendency towards the use of finite complementation. In this context, Cristofaro (1996) has claimed that the Classical opposition whereby the accusative and infinitive is used for non-factive complements, and ö $\tau$ เ with the indicative and the accusative and participle for factive ones, is disappearing, ö $\tau$ ı being used as a 'generic' complementiser. In this article, I investigate to what extent Cristofaro's (1996) claim of the pragmatic neutralisation of complementation patterns can be upheld, and whether it could be claimed that a new pragmatic opposition, in terms of 'register', is being established. For this purpose, I turn towards documentary papyri, a corpus which is particularly fruitful for socio-historical investigations.
\end{abstract}

\section{Keywords}

Ancient Greek - complementation - documentary papyri - factivity - register - diachrony

* I would like to thank Dag Haug, as well as two anonymous referees for their helpful comments on an earlier version of this article. Parts of the article were presented at the Post-classical Greek: Intersections of Philology and Linguistics conference (Mainz, February 15, 2016), the Language in Style conference (Oxford, May 20, 2016), and the 23rd International Congress of Byzantine Studies (Belgrade, August 25, 2016). My work was funded by the Fund for Scientific Research-Flanders (grant no. FWO13/PDo/oo8).

(C) KLAAS BENTEIN, 2017 | DOI: 10.1163/15699846-01701002

This is an open access article distributed under the terms of the Creative Commons 


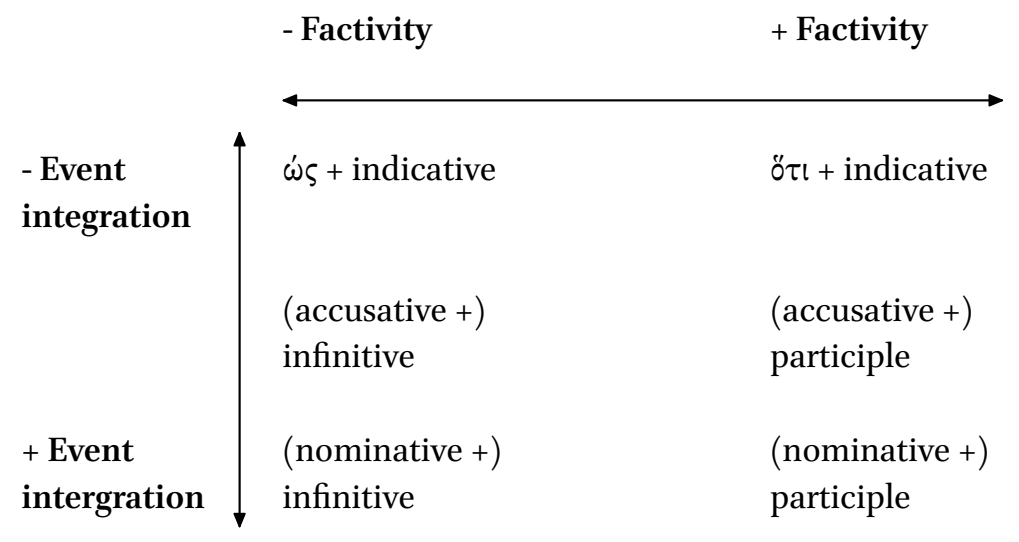

FIGURE 1 Semantic/pragmatic factors governing complementation in Classical Greek ${ }^{1}$

As Joseph (1987:366) writes, the system of verbal complementation forms one of the most elaborate parts of Ancient Greek syntax. Next to infinitives and participles, which accompanied the main verb directly, Ancient Greek also had a great variety of subordinating conjunctions which could combine with finite verb forms in the indicative, subjunctive, or optative moods to form verbal complements. Cristofaro $(1995,1996,2008,2012)$ has shown in various publications that the distribution of these Classical complementation patterns was not random: she has stressed the importance of the notions 'factivity' and 'event integration', factivity referring to whether the truth value of the complement is presupposed, ${ }^{2}$ and event integration to whether there is participant coreference, spatio-temporal contiguity, control, etc. ${ }^{3}$ This can be represented as in Figure $1 .^{4}$

This Figure shows that finite complementation patterns tend to be used

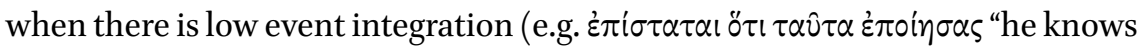
that you did that", with two separate subjects), whereas non-finite complementation patterns are typically used when there is high event integration (e.g.

1 Note that I do not make a distinction between non-factivity and contra-factivity, as Cristofaro (1996) does.

2 See further Lyons (1977:793-809).

3 See further Givón (2001.2:40-58).

4 Note that this figure displays only a limited number of complementation patterns, not the entire complementation system. 


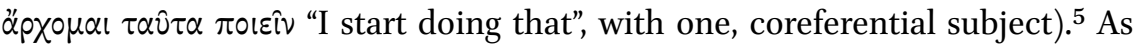
for factivity, $\dot{\omega} \varsigma$ with the indicative and the nominative/accusative and infini-

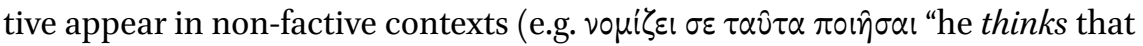
you did that"), whereas ö $\tau$ เ with the indicative and the nominative/accusative

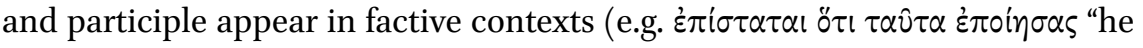
knows that you did that").

In the Post-classical period, things start to change: ${ }^{6}$ finite complementation patterns, ö $\tau$ เ with the indicative among others, are favoured. ${ }^{7}$ The infinitive and participle, on the other hand, gradually disappear from the complementation system. ${ }^{8}$ Cristofaro has even argued that ö $\tau$ ı came to be used as a 'forma completiva generica, del tutto indipendente dallo status semantico della completiva' (1996:151), as a result of which it would have become impossible to express modal distinction through the choice of a complement structure.

Evidently, the process that I am describing here took place over a very long period of time. Cristofaro (1996:132), for example, notes that a reduction in the use of the accusative and infinitive took place between the second century $\mathrm{BC}$ and the sixth century AD, while its eventual disappearance should be situated in between the tenth and the sixteenth century AD. This does not mean that the distribution of complementation patterns was entirely random: studies by Hult (1990:147-207), Kavčič (2005), James (2008) and Sampanis (2011), among others, have shown that non-finite complementation patterns appear more often in texts written in a higher register. ${ }^{9}$

In this article, I would like to investigate in somewhat greater detail whether indeed a new pragmatic opposition was being established in Post-classical (and Early Byzantine) Greek - that is, whether instead of factivity, register now became the determining factor in the choice for a complementation pattern.

5 For further details on the subject of infinitive clauses, see Luraghi (1999). Luraghi shows, among others, that under some conditions the accusative can be used even when the subject of the accusative and infinitive-clause is coreferential with that of the governing verb.

6 A number of reasons can be mentioned for this process: language-internal ones, such as the complexity of participial morphology, and the redundancy of the Classical complementation system; language-external ones, such as language contact with Latin and Coptic. See further James (2001/2005:154-156; 2008:57).

7 See e.g. Mayser (1926:44) with regard to Ptolemaic documentary papyri.

8 As Joseph (1987:367) notes, in Modern Greek 'the spread of finite complementation is complete ... and there are no instances of non-finite complementation remaining'.

9 For a definition of the notion 'register', see e.g. James (2008:35): 'a register is a variety of the language which is defined according to use, that is, for example, according to the purpose of the communication, its subject matter, and the relationship between the speaker and the addressee'. James (2008) distinguishes between a 'high', 'middle', and 'low' register. 
For this purpose, I will focus on structures of mid- to low-event integration, more specifically ö $\tau \iota$ with the indicative, the accusative and infinitive, and the accusative and participle. ${ }^{10}$

2

\section{Corpus}

My analysis is based on a corpus of documentary texts ranging from the first until the eighth century AD. ${ }^{11}$ To be more specific, I have analysed all letters and petitions contained within so-called 'archives', ${ }^{12}$ that is, groups of texts that have been collected in antiquity by persons or institutions, for example because they were useful and needed to be kept, or because they had sentimental value. ${ }^{13}$ Letters are more numerous in my corpus than petitions: there are more than 1300 letters, but only 400 petitions.

Working with documentary texts has several important advantages: they have been preserved in great number for almost a millennium, often can be dated, and are affected relatively little by the linguistic purism that arose in the Hellenistic period..$^{14}$ Crucial for our present purposes is that they are also contextually diverse. ${ }^{15}$ This allows one to investigate the social context in which complementation patterns are used to a much greater extent than is possible with other, literary sources.

This is not to say that working with documentary papyri is completely unproblematic. One important methodological problem involves the so-called 'scribal issue': it is often unclear to what extent ${ }^{16}$ a scribe was involved in composing the document. For our present purposes, I will assume that even if a scribe was involved, he did not have any reason to differentiate his language

10 I am not taking into account $\dot{\omega} \varsigma$ with the indicative, which occurs less frequently. See my previous observations (Bentein 2015b:110-112).

11 Including the Ptolemaic period (III-I BC) in the analysis might be diachronically enlightening, as one of the reviewers suggests. This is something which I have to leave for further research, however.

12 An overview of these archives and the texts contained within them can be found at http:// www.trismegistos.org/arch/index.php.

13 Cf. Vandorpe (2009:238-240).

14 Cf. Sampanis (2011:113).

15 Cf. James (2008:37).

16 Richards (2004:64-80), for example, has proposed to distinguish between three categories: (i) the scribe as transcriber, (2) the scribe as contributor, and (3) the scribe as composer. 
TABLE 1 Overview of examples ${ }^{17}$

\begin{tabular}{|c|c|c|c|c|c|}
\hline & Number & Lines & ö $\tau \iota+$ ind. & ACI & ACP \\
\hline Letters & 1333 & 22501 & 387 & 995 & $5^{2}$ \\
\hline MPG (I-III AD) & 836 & 14826 & 214 & 656 & 21 \\
\hline LPG (IV-VI AD) & 294 & 4991 & 140 & 258 & 9 \\
\hline EBG (VII-VIII AD) & 203 & 2684 & 33 & 81 & 22 \\
\hline Petitions & 395 & 8929 & 17 & 331 & 34 \\
\hline MPG (I-III AD) & 235 & 5224 & 9 & 136 & 17 \\
\hline LPG (IV-VI AD) & 160 & 3705 & 8 & 195 & 17 \\
\hline EBG (VII-VIII AD) & o & o & o & o & o \\
\hline Total & 1728 & 31430 & 404 & 1326 & 86 \\
\hline
\end{tabular}

from what would have been expected in that particular social context. It is quite likely, of course, that not every scribe had the same sociolinguistic competence.

Table 1 shows the total number of instances for each of the three complementation structures under analysis.

This table shows that in our corpus the accusative and infinitive is still predominant, with over 1300 examples. ö $\tau$ เ with the indicative is attested secondmost frequently, with over 400 examples. For the accusative and participle, there are only 86 instances.

\section{Factivity: the 'classical' pragmatic opposition}

In the first part of this article, I investigate the contexts in which the accusative and infinitive, the accusative and participle, and ö $\tau \iota$ with the indicative are used. A general overview of the distribution of these complementation patterns is given in Table 2.

As this Table shows, I distinguish between six verb classes: (i) causative verbs, (ii) verbs of ordering, (iii) verbs of perception, (iv) verbs of mental state, (v) psychological verbs, and (vi) verbs of communication. ${ }^{18}$ For my analysis, I have grouped these verb classes into four major groups: (i) causative verbs and

\footnotetext{
17 In this and other tables, MPG stands for 'Middle Post-classical Greek'; LPG for 'Late Postclassical Greek'; в вG for 'Early Byzantine Greek'; ACI for 'accusativus cum infinitivo'; and ACP for 'accusativus cum participio'.

18 There are also some instances of complementation patterns after impersonal verbs. I have
} 
TABLE 2 Distribution of complementation patterns according to verb class ${ }^{19}$

\begin{tabular}{llccc}
\hline & Factivity & ö $\tau$ + indicative & ACI & ACP \\
\hline Causative verbs & no & NA & $148(11 \%)$ & NA \\
Verbs of ordering & no & NA & $138(10 \%)$ & NA \\
Verbs of perception & yes & $53(13 \%)$ & $33(2 \%)$ & $50(58 \%)$ \\
Verbs of mental state & yes & $137(34 \%)$ & $36(3 \%)$ & $14(16 \%)$ \\
Psychological verbs & possibly & $38(9 \%)$ & $658(50 \%)$ & $9(11 \%)$ \\
Verbs of communication & possibly & $176(44 \%)$ & $314(24 \%)$ & $13(15 \%)$ \\
Total & & 404 & 1326 & 86 \\
& & & & \\
\hline
\end{tabular}

verbs of ordering, (ii) verbs of perception and mental state, (iii) psychological verbs, and (iv) verbs of communication.

\subsection{Causative verbs and verbs of ordering}

Causative verbs and verbs of ordering are semantically similar, as their complement is always situated in the future. They have what Noonan (2007 [1985]:102) calls 'determined time reference'. As such, they are also non-factive in nature: since the complement is situated in the future, the truth of it cannot be presupposed. Some examples of causative verbs are $\varkappa \omega \lambda \nu \omega$ "I hinder, prevent",

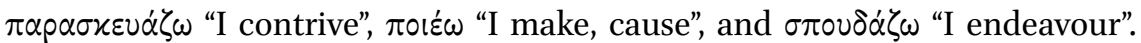
Examples of verbs of ordering are $\dot{\varepsilon} \pi \alpha \gamma \dot{\varepsilon} \lambda \lambda \omega$ "I command", $\varepsilon \nu \tau \dot{\varepsilon} \lambda \lambda \mu_{\mu l}$ "I enjoin", $\dot{\varepsilon} \pi \sigma \tau \dot{\varepsilon} \lambda \lambda \omega$ "I give orders", and $\chi \varepsilon \lambda \varepsilon \varepsilon^{\prime} \omega$ "I order".

As Table 2 indicates, all of the examples after these two verb classes are formed with the accusative and infinitive. For an illustration, consider (1):

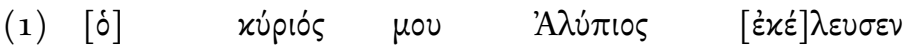

ART.NOM lord:NOM 1SG.GEN Alypios:NOM order:AOR.3SG

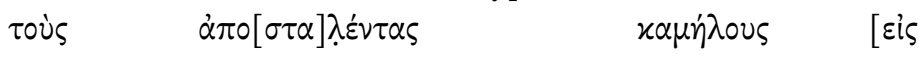

ART.ACC.PL send:PTCP.AOR.PASS.ACC.PL camels:ACC.PL to

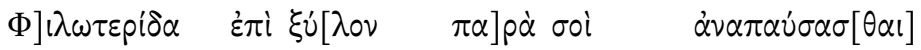

Philoteris:ACC for wood:ACC with 2SG.DAT rest:INF.AOR.

not included these, since here the complement has a different syntactic status (compare Hult 1990:164-166, who distinguishes between 'object clauses' and 'subject clauses').

19 For a typology of so-called 'complement taking predicates', see Noonan (2007[1985]:120145). My own classification is, to a large extent, based on Levin's (1993). 
'My lord Alypius has ordered that the camels that have been sent to Philoteris for the wood should rest at your place.' (P.Prag.1.106, ll. 2-7 $(259 \mathrm{AD}))$

The central administrator Ischyrion writes to the phrontistês Heroninus that it has been ordered that certain camels should rest at Heroninus' place. Note that while the resting of the camels is situated in the future, an aorist infinitive is used. There is no ambiguity, however, since future time reference is the only option after verbs of ordering.

In many examples, it is not entirely clear whether we are truly dealing with an accusative and infinitive construction. In an example such as $\dot{\varepsilon} x \varepsilon \dot{\varepsilon}[\lambda] \varepsilon v \sigma \varepsilon \nu$

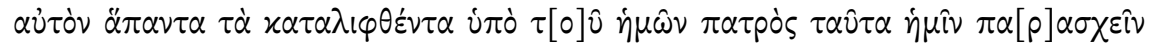
(P.Cair.Isid.64, ll. 11-13 (ca. 298AD)) "he ordered him (i.e. Chaeremon) to turn over to us all the property that had been left by our father" [tr. Youtie], it is unclear ${ }^{20}$ whether $\alpha \dot{\tau} \tau \dot{0} v$ functions as the subject of an accusative and infinitive construction ("he ordered that he should turn over"), or rather as the accusative of the addressee ${ }^{21}$ ("he ordered him to turn over");22 similarly, in an example,

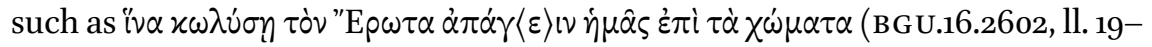
$20(14 / 13$ в $)$ ) "so that he can prevent Eros from sending us to the dikes" [tr. Brashear], it is not entirely clear whether the accusative functions as the object of the governing verb ("so that he can prevent Eros to send"), or rather as the subject of an accusative and infinitive construction ("so that he can prevent that Eros sends"). This ambiguity lies at the origins of the accusative and infinitive construction. ${ }^{23}$ From there, the use of the construction spread to other verb classes. ${ }^{24}$ In the present article, I have included all such ambiguous examples in the statistics.

As Table 2 shows, the use of ö $\tau$ เ with the indicative and the accusative and participle is unattested after causative verbs and verbs of ordering. As such, we

20 It is true, as Kavčič (2005:132) notes, that in Post-classical Greek the dative was also used to indicate the addressee after verbs such as $\chi \varepsilon \lambda \varepsilon \dot{\omega} \omega$. However, it is doubtable whether we can conclude on this basis that all examples with the accusative are non-ambiguous.

21 Contrast with (1), where the camels are clearly not the addressee.

22 In order to avoid this ambiguity, many writers use a passive accusative and infinitive (cf. Mihevc-Gabrovec 1972; Hult 1990:166-167, 206; Kavčič 2005:140), without the addressee being expressed, or the nominative and infinitive, with the addressee in the dative case (Kavčič 2005:134-135).

23 Or at least partly. See further Cristofaro (2012) (with references to older literature).

24 Cf. Kavčič (2005:129-130). Note that this explains the relationship between the accusative and infinitive construction and non-factivity. 
TABLE 3 Complementation after verbs of

ordering/causative verbs (diachronic)

\begin{tabular}{ccrc}
\hline & ö $\tau$ + ind. & ACI & ACP \\
\hline MPG (I-III AD) & NA & 95 & NA \\
Causative verbs & NA & 44 & NA \\
Verbs of ordering & NA & 51 & NA \\
LPG (IV-VI AD) & NA & 136 & NA \\
Causative verbs & NA & 65 & NA \\
Verbs of ordering & NA & 71 & NA \\
EBG (VII-VIII AD) & NA & 55 & NA \\
Causative verbs & NA & 39 & NA \\
Verbs of ordering & NA & 16 & NA \\
\hline
\end{tabular}

cannot say that ö $\tau$ as a complementiser was pragmatically 'neutral', as Cristofaro (1996) would have it. This is not to say that the accusative and infinitive did not retreat after these verbs; rather, a new complementation pattern was introduced: iv $\alpha$ with the subjunctive. ${ }^{25}$ While this complementation pattern can be found already at an early stage (e.g. in the New Testament), examples remain limited in the papyri. ${ }^{26}$ As Table 3 shows, the accusative and infinitive remains well attested, even in Early Byzantine Greek.

\subsection{Verbs of perception and verbs of mental state}

Verbs of mental state and verbs of perception are semantically similar. As Cristofaro notes:

There is a conceptual link between the sensory perception of a state of affairs and knowledge that a state of affairs is the case, insofar as a process of sensory perception implies that the perceiver acquires knowledge about the perceived state of affairs.

2012:344

25 See De Boel (1999); Bentein (2015b:115-118). In the latter publication, I also mention the use of syndetic and asyndetic parataxis after verbs of ordering and causative verbs (Bentein 2015b:107-110).

26 Cf. Bentein (2015b:117). 
Both verb classes are factive in nature. Some verbs of perception that are

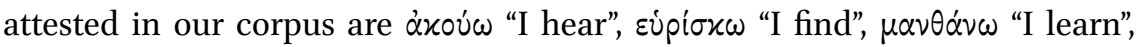
and opóc "I see". Verbs of mental state form a more restricted verb class: some

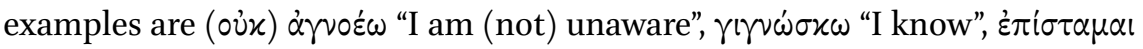

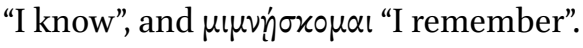

Since the above-mentioned verbs are factive in nature, we would expect the use of ö $\tau$ with the indicative and the accusative and participle, which is also what we find. ${ }^{27}$ As Table 2 shows, ö $\tau$ เ with the indicative is used more frequently than the accusative and infinitive (with 190 vs. 69 examples), and the accusative and participle is attested more frequently than the accusative and infinitive after verbs of perception (with 50 vs. 33 examples). ${ }^{28}$ For an example, consider (2):

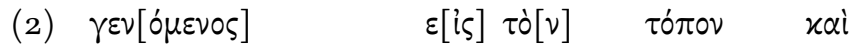
come:PTCP.AOR.NOM to ART.ACC place:ACC and

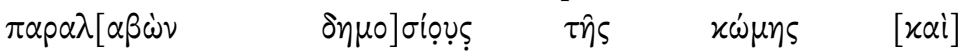

take:PTCP.AOR.NOM officials:ACC.PL ART.GEN village:GEN and

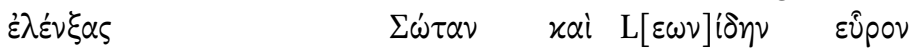

question:PTCP.AOR.NOM Sotas:ACC and Leonides:ACC find:AOR.1SG

$\alpha \dot{\tau} \tau \dot{\eta}[\nu \quad \dot{\varepsilon}] \mu \pi \rho \eta \sigma \theta \varepsilon \hat{\imath} \sigma \alpha \nu$

DEM.ACC burn:PTCP.AOR.PASS.ACC

'I went to the place, and taking with me the officials of the village, I questioned Sotas and Leonides and found that it had been burned.' (P.Cair. Isid.124, ll. 8-13 (298AD))

In this letter to the strategus, Aurelius Sarapion reports that he went to the village of Karanis and found that the grain on the threshing floor had been

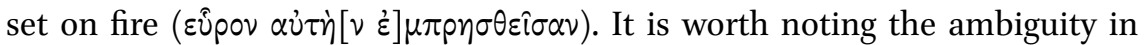
this example: the accusative can be understood as the object of the governing verb ("I found it burned") or as the subject of the accusative and participle construction ("I found that it had been burned"). Similarly to what we have

27 This was also the standard situation in the Classical period (see Smyth 1984[1920]:470, Hult 1990:162). On the expansion of ö $\tau$ ı with the indicative vis-à-vis the accusative and participle, see Hult (1990:206).

28 Compare James (2008:105): '[the accusative and infinitive] was the least widely used of the three complement structures with verbs of perception'. The accusative and participle did give way to the accusative and infinitive, however. In Classical and Early Post-classical times, the accusative and participle was the standard pattern after verbs such as $\dot{\alpha}$ xov́ $\omega$ (see e.g. James 2008:41), but this is no longer the case. 
seen for the accusative and infinitive, this ambiguity lies at the origins of participial complementation. ${ }^{29}$ It may, as James (2001/2005:166) claims, also explain the relatively long use of the accusative and participle construction in Post-classical and Byzantine Greek. ${ }^{30}$

Already in the Classical period, the accusative and infinitive is attested as an alternative, but usually with a difference in meaning, ${ }^{31}$ whereby the governing verb becomes non-factive in nature. ${ }^{32}$ In documentary papyri, however, the accusative and infinitive is used even after verbs which are clearly factive in nature. For example, the accusative and infinitive occurs quite frequently after the verb $\gamma\left(v \omega \dot{\omega} \sigma \kappa \omega\right.$ "I know". 33 This is shown in the following example: ${ }^{34}$

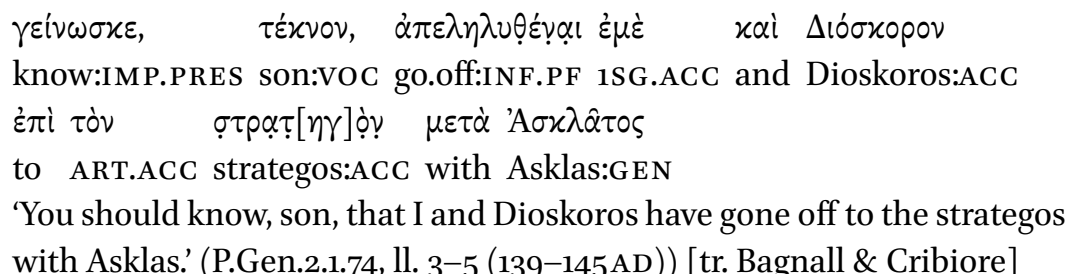

Herais writes to her son Agrippinus, informing him that she went off to the strategus. Note how $\gamma \varepsilon i v \omega \sigma \kappa \varepsilon$ "know" is followed by the accusative and infinitive, rather than ö $\tau$ เ with the indicative. As Table 4 shows, such examples can be found until the fourth century AD. Afterwards, only ö $\tau \iota$ with the indicative is used. The accusative and participle, too, is no longer attested after verbs of mental state; it can still be found until the eighth century AD after verbs of perception, however.

29 Cf. Cristofaro (2012:342).

30 A thesis which is confirmed by the fact that there are (almost) no more examples after verbs of mental state in LPG and EBG (see Table 4), where such an ambiguity does not exist.

31 See e.g. Smyth (1984[1920]:474-476).

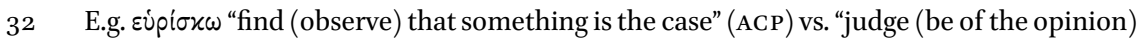
that something is the case" (ACI); $\alpha x o v \omega \omega$ "hear that something is the case" (ACP) vs. "hear (as a rumour) that something is the case" (ACI). $\alpha x \circ v$ w could also be followed by the genitive and participle in Classical times. For the meaning difference between the two participial constructions, see e.g. Rijksbaron (2002:118, n. 1).

33 In particular $\gamma^{\prime}(\omega \omega \sigma \kappa \varepsilon$, which serves as a disclosure formula at the beginning of letters.

34 For similar examples of the ACI in a factive context, see e.g. P.Brem.48, ll. 3-4 (118AD); P.Mich.6.423, l. 11 (197 AD); P.Flor.2.131, ll. 2-4 (257 AD); P.Kell.1.76, ll. 25-27 (IV AD); P.Neph.2, ll. 6-8 (IVAD). 
TABLE 4 Complementation after verbs of perception and mental state (diachronic)

\begin{tabular}{lrrr}
\hline & ö $\tau$ + ind. & ACI & ACP \\
\hline MPG (I-III AD) & 104 & 50 & 32 \\
Verbs of perception & 25 & 30 & 21 \\
Verbs of mental state & 79 & 20 & 11 \\
LPG (IV-VI AD) & 70 & 19 & 13 \\
Verbs of perception & 20 & 3 & 10 \\
Verbs of mental state & 50 & 16 & 3 \\
EBG (VII-VIII AD) & 16 & NA & 19 \\
Verbs of perception & 8 & NA & 19 \\
Verbs of mental state & 8 & NA & NA \\
& & & \\
\hline
\end{tabular}

\subsection{Psychological verbs}

Psychological verbs have some affinity with verbs of mental state: both verb classes are concerned with mental activities. Some examples of psychological

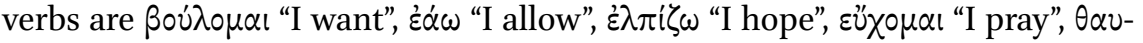

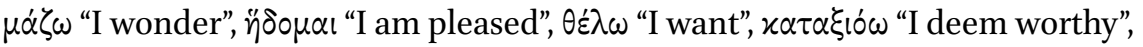

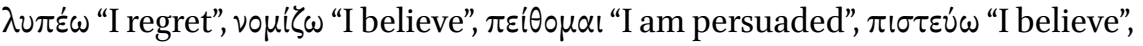
$\pi p \circ \sigma \delta 0 x \alpha \dot{\alpha} \omega$ "I expect", and $\sigma u \gamma x \omega \rho \tilde{\varepsilon} \omega$ "I concede". Contrary to verbs of mental state, however, psychological verbs are not necessarily factive: those verbs which express a wish or an opinion (e.g., $\dot{\varepsilon} \lambda \pi i \zeta \omega$ "I hope", vopi $\zeta \omega$ "I believe") ${ }^{35}$ are non-factive. Verbs expressing a certain disposition towards the complement

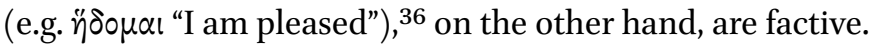

The use of the accusative and infinitive is very often attested in our corpus, with over 600 (!) examples. For an example, consider (4):

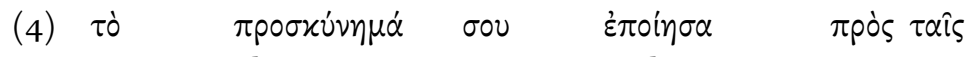

ART.ACC obeisance:ACC 1SG.GEN make:AOR.1SG at ART.DAT.PL

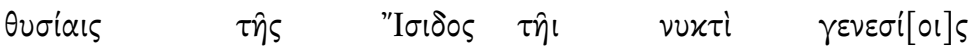
festival:DAT.PL ART.GEN Isis:GEN ART.DAT night:DAT birthday:DAT.PL

\footnotetext{
35 Noonan (2007[1985]:124-126, 132-135) speaks of 'desiderative predicates' and 'propositional attitude predicates'. Note that Noonan also classifies some factive verbs (such as "know") as 'propositional attitude predicates'.

36 Noonan (2007[1985]:127-129) speaks of 'commentative predicates'.
} 


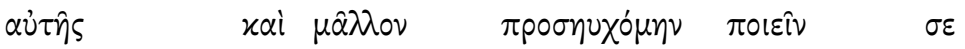

$$
\begin{aligned}
& \text { DEM.GEN.SG.F and exceedingly pray:IMPF.1SG do:INF.PRES 2SG.ACC } \\
& \tau \dot{\alpha}(\varsigma) \quad \quad \dot{\alpha} \rho \rho \tau \dot{\alpha} \tau \alpha \varsigma \quad \pi \rho \circ \% \pi \dot{\alpha} \varsigma
\end{aligned}
$$

ART.ACC.PL fine:SUP.ACC.PL success:ACC.PL

'I made the obeisance for you at the festival of Isis on the night of her birthday, and I also prayed for your prosperity and success.' (P.Brem.15, ll. 31-34 (II AD)) [tr. Pucci Ben Zeev]

The architect Herodes writes to Apollonius the strategus, and concludes his letter by saying that he has prayed that Apollonius will do well. Whereas in Classical times, a future, rather than a present infinitive would be used after verbs of 'hoping', 'expecting', 'swearing', etc., ${ }^{37}$ in our corpus the future is largely avoided: there are only thirteen examples, ${ }^{38}$ almost half of which stem from one related group of texts, the so-called archive of Aurelius Ammon (P.Ammon).

The frequency of the accusative and infinitive after psychological verbs can, in part, be explained by the occurrence of formulaic phrases, such as

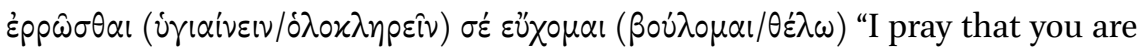

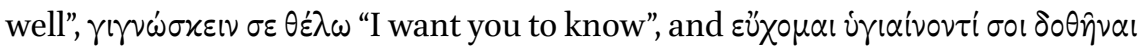

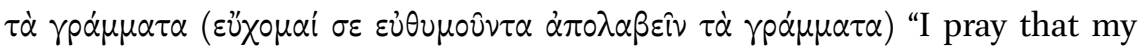

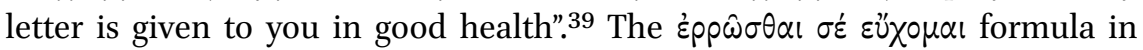
particular, which could be used both at the beginning and end of a letter, has a serious impact: it accounts for an impressive $65 \%$ of the examples, with 428 attestations. After the fourth century AD, however, most of these formulae

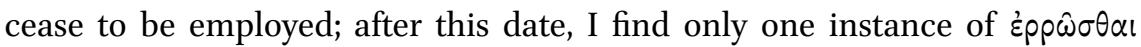

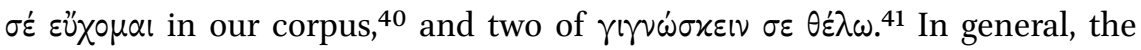
accusative and infinitive is much less often employed after the fourth century AD, with only 38 instances (see also Table 5 ).

As Table 2 shows, the accusative and participle is almost unattested, with only 9 examples. ő $\tau$ with the indicative can be found slightly more often,

37 Cf. Hult (1990:163).

38 вGU.16.2623, ll. 10-11 (1о вС); P.Brem.5, ll. 8-9 (II AD); P.Giss.Apoll.24, 3, ll. 12-13 (II AD); P.Mil.Vogl.2.76, ll. 8-9 (II AD); P.Ammon.2.33, ll. 8-9 (348AD); P.Ammon.2.33, ll. 9-10 (348 AD); P.Ammon.2.37, l. 21 (348 AD); P.Ammon.2.38, l. 20 (348 AD); P.Ammon.2.40, ll. 1112 (348 AD); P.Ammon.2.41, ll. 21-22, 28 (348 AD); P.Ammon.2.45, ll. 4-5 (348 AD); P.Oxy.48. 3421, ll. 12-13 (IVAD).

39 On these formulae, see most recently Nachtergaele (2015).

40 BGU.19.2773, l. 11 (VAD).

41 P.Apoll.41, l. 3 (VII AD); P.Ness.3.75, l. 1 (VII AD). 
with 38 examples. ${ }^{42}$ ö $\tau$ เ with the indicative is mostly used in factive contexts, that is, after Noonan's $(2007[1985])$ 'commentative predicates. 43 This Classical usage is not always upheld, however: the pattern also appears after non-factive verbs, as does the accusative and participle. Consider the following two examples: ${ }^{44}$

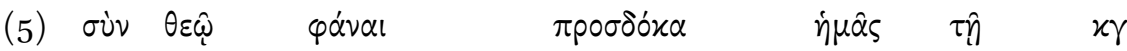
with God:DAT speak:INF.PRES expect:IMP.PRES 1PL.ACC ART.DAT 23

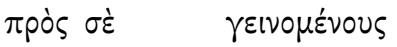

to 2SG.ACC come:PTCP.PRES.ACC.PL

'If it pleases God, expect that we will be coming to you on the 23d.' (P.Flor.2.127, ll. 2-3 (266AD))

(6) $\dot{\varepsilon} \lambda \pi i \zeta \omega$

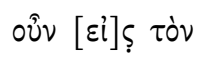

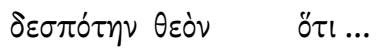

hope:PRES.1SG so to

$\pi \lambda \eta p o \hat{\tau} \tau \alpha l \ldots$ $\tau \dot{\alpha}$

ART.ACC lord:ACC God:ACC COMP

fulfill:PRES.PASS.3SG ART.ACC.PL order:PTCP.AOR.PASS.ACC.PL $[\pi] \alpha \rho \dot{\alpha} \tau \hat{\eta} \varsigma \quad \dot{v} \mu \hat{\omega} \nu \quad[\dot{\xi} \xi] \circ[v] \sigma i \alpha \varsigma$

by ART.GEN 2PL.GEN lordship:GEN

'I hope therefore to our Lord God that ... the commands of your lordship ... will be executed.' (P.Oxy.16.1829, 1l. 7-10 (ca. 577-583AD))

In the first of these examples, the general manager Alypius informs Heroninus that he will be coming on the 23rd; in the second, an unknown individual expresses his wish that the commands of Flavius Strategius will be executed. In both cases, a desiderative verb governs the complement clause: in (5), the

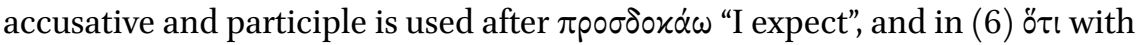
the indicative is used after the verb $\dot{\varepsilon} \lambda \pi i \zeta \omega$ "I hope". Note how here, too, the future is avoided, even though the complement has future time-reference.

42 Contrast with Mayser's (1926:47) observations on the Ptolemaic papyri, who notes that 'die verba putandi haben wie in der klassischen Sprache fast ausschließlich den Infinitiv bei sich.'

43 For some examples, see e.g. P.Brem.58, ll. 7-8 (II AD); P.Sarap.103bis, ll. 3-6 (II AD); P.Sarap. 85, l. 4 (II AD); P.Apoll.32, l. 2 (713AD).

44 For similar examples, see e.g. BGU.1.248, l. 29 (75-76 AD); P.Lond.6.1926, ll. 13-15 (IVAD); SB.12.10803, ll. 6-9 (IV AD); P.Oxy.16.1940, l. 3 (VI/VII AD); P.Apoll.37, l. 6 (708-709AD) (ö เ with the indicative); P.Oxy.16.1868, ll. 2-3 (VI/VII AD) (ACP). 
TABLE 5 Complementation after psychological

verbs (diachronic)

ö $\iota+$ ind. ACI ACP

\begin{tabular}{lrrr}
\hline MPG (I-III AD) & 20 & 471 & 1 \\
LPG (IV-VI AD) & 14 & 174 & 5 \\
EBG (VII-VIII AD) & 4 & 13 & 3
\end{tabular}

\subsection{Verbs of communication}

Quite a few verbs of communication are attested in our corpus. Some examples

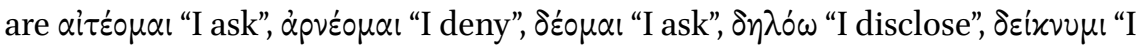

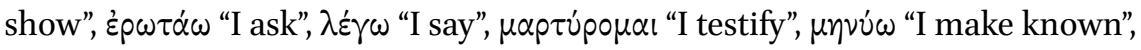

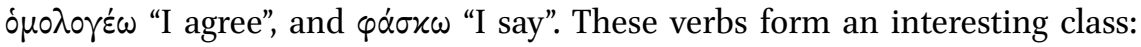
whereas most of the verbs and verb classes that were mentioned in the previous sections have a complement that is either factive or non-factive in nature, verbs of communication can be followed by both. ${ }^{45}$

As such, verbs of communication could be followed by various complementation patterns already in the Classical period, most importantly ö $\tau$ with the indicative in factive contexts, and $\dot{\omega} \varsigma$ with the indicative and the accusative and infinitive in non-factive ones. In our corpus, both the accusative and infinitive and ö $\tau$ เ with the indicative are well attested, with 314 vs. 176 examples respectively; the accusative and participle is much less frequent, with only 13 examples.

The main use of the accusative and infinitive after communicative verbs is in non-factive contexts. Consider the following example: ${ }^{46}$

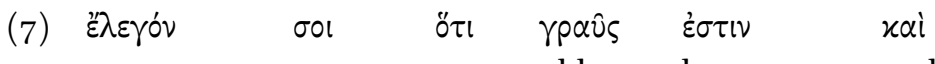

say:IMPF.1SG 2SG.DAT COMP old:NOM be:PRES.3SG and

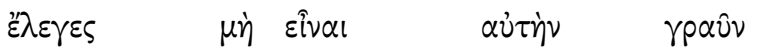

say:IMPF.2SG not be:INF.PRES DEM.ACC.F old:ACC

'I told you that [the camel] was old and you said to me that it was not old." (P.Gen.4.172, ll. 7-9 (IV/VAD))

45 Compare Cristofaro (1995:100).

46 For similar examples, see e.g. P.Mich.10.581, ll. 14-15 (ca. 126-128AD); P.Lips.1.34dupl, l. 13 (ca. 375 AD). 
Athanasius writes to Ammonius with regard to a camel he bought: while Athanasius said that it was an old camel, Ammonius pretended it was not. The contrast between what the writer, Athanasius, presupposes to be true or not is nicely brought out by the use of different complement clauses: ö $\tau$ เ with the indicative (the camel is old) vs. the accusative and infinitive (the camel is not old).

More often, the accusative and infinitive is attested in another type of nonfactive context: when verbs of communication are followed by infinitival complementation, they can be construed as verbs of ordering, with the complement being situated in the future. Consider the following example: ${ }^{47}$

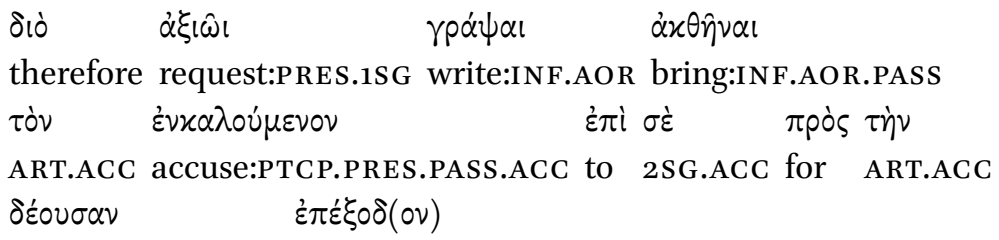

fit:PTCP.PRES.ACC punishment:ACC

'Wherefore I request you to write that the accused man be brought before you for fitting punishment.' (P.Ryl.2.143, 1l. 19-22 (38AD)) [tr. Johnson et al.]

In this petition, Heraclas requests that a shepherd be brought before the strate-

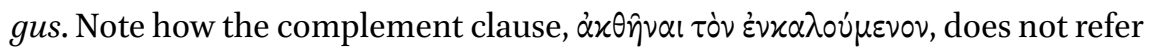
to something which happened in the past, but rather to an order: ${ }^{48}$ in terms of speech function, the complement is not a statement (proposition), but a command (proposal). ${ }^{49}$ Since the aorist infinitive is used for both types, ${ }^{50}$ the

47 For similar examples, see e.g. P.Ryl.2.144, ll. 23-24 (38AD); BGU.2.597, ll. 23-24 (75AD); P.Ryl.2.231, ll. 3-4 (40 AD); P.Abinn.28, ll. 26-27 (342-351 AD); P.Oxy.48.3396, ll. 7-8, $15^{-17}$ (IVAD).

48 Compare my observations on the use of i $\alpha \alpha$ with the subjunctive after communicative verbs (Bentein 2015b:116-117).

49 Cf. Halliday \& Matthiesen (2014:510-511). Halliday \& Matthiesen (2014:134-139) define four major speech functions-offer, command, statement and question-which they classify into two major types: proposals (offer/command) and propositions (statement/question).

$5^{\circ}$ There are a few examples with the future infinitive; see e.g. CPR.15.8, ll. 8-11 (15AD); BGU.2.597, ll. 24-25 (75AD); P.Sarap.9o, l. 12 (ca. 98-117AD); P.Sarap.87, ll. 4-5 (II AD). Alternatively, the present infinitive can be used; see e.g. P.Mich.8.465, ll. 23-24 (107AD); P.Mich.8.499, l. 15 (II AD); P.Tebt.2.335, ll. 15-16 (ca. 165AD?); P.Oxy.41.2997, ll.16-17 (214AD). 
speech function of the complement may be ambiguous. This ambiguity is further complicated by the fact that the aorist is used for both past and future statements. Consider the following two examples:

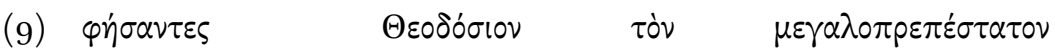
say:PTCP.AOR.NOM Theodosios:ACC ART.ACC magnificent:SUP.ACC

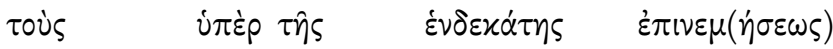
ART.ACC.PL for ART.GEN eleventh:GEN indiction:GEN

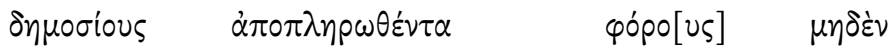
public:ACC.PL pay:PTCP.AOR.PASS.ACC taxes:ACC.PL nothing:ACC

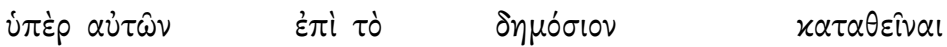
for DEM.GEN.PL in ART.ACC public treasury:ACC deposit:INF.AOR '... saying that the most magnificent Theodosius had received the public taxes for the eleventh indiction, but had deposited nothing on their account in the public treasury.' (s B.6.9102, ll. 8-13 (547-549AD)) [tr. Salomon]

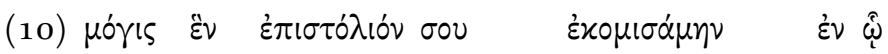
barely one letter:ACC 2SG.GEN receive:AOR.1SG in REL.DAT

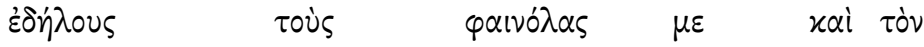
inform:IMPF.2SG ART.ACC.PL cloak:ACC.PL 1SG.ACC and ART.ACC

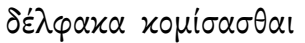
pig:ACC receive:INF.AOR 'I received barely one letter from you, in which you informed me that I should receive the cloaks and the pig.' (P.Mich.8.496, ll. 8-11 (II AD)) [tr. Youtie \& Winter]

In both examples, an aorist infinitive is used after a verb of communication. This infinitive has a somewhat different function from what we have seen in (8), however: in (9), $x \alpha \tau \alpha \theta \varepsilon i v \alpha \iota$ refers to a past event (not having deposited taxes), whereas in (10) xopi $\sigma \alpha \sigma \theta \alpha$ r refers to a future event (the receiving of cloaks and a pig). Context usually resolves this ambiguity, but it may be considered another element contributing to the loss of the accusative and infinitive.

ö $\tau$ เ with the indicative is not solely used in factive contexts. Consider the following example:
(11) $\dot{\varepsilon} \pi \varepsilon ́ \gamma \nu \omega \nu$
$\sigma \varepsilon$
$\delta \eta \lambda \circ \hat{\nu \tau \tau \alpha}$
oủx ợ $\tau[\mathrm{l}]$ oủx.
learn:AOR.1SG 2SG.ACC state:PTCP.PRESS.ACC not COMP not

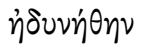 $\dot{\alpha} \pi \alpha p \tau i \sigma \alpha l$ $\tau \dot{\alpha}$
be able:AOR.1SG attend to:INF.AOR ART.ACC.PL 


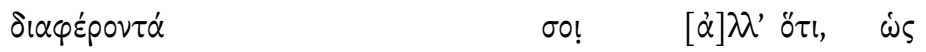

be of interest to:PTCP.PRES.ACC.PL 2SG.DAT but COMP AS

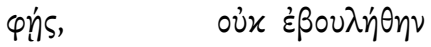

say:PRES.2SG not want:AOR.1SG

'I learned that you state, not that I was unable to attend to your affairs, but that, as you say, I was unwilling.' (P.Mich.8.486, ll. 4-6 (II AD))

The author of the letter, Sempronius Clemens, clearly does not agree with the contents of the second complement to $\delta \eta \lambda 0 \hat{v} \tau \tau$, that he would have been unwilling rather than unable to attend to the addressee's affairs. ${ }^{51}$

ö $\tau$ เ with the indicative can also be found after $\varphi \eta \mu i$ "I say",52 where Classical Greek would use an accusative and infinitive. This extension of ö $\tau$ ı with the indicative to non-factive contexts could, perhaps, be attributed to the loss of $\dot{\omega} \varsigma$ as a complementiser in the Post-classical period. ${ }^{53}$

The use of the accusative and participle is mainly limited to verbs of instructing/showing ( $\alpha \dot{\pi} 0 \delta \varepsilon i x \nu \cup \mu l$ "I point out", $\delta 1 \delta \alpha \sigma \varkappa \omega$ "I instruct"). ${ }^{54}$ There is only a single example after a verb of saying: P.Giss.Apoll.22, 1. 6 (116-120 AD).

James (2008) has claimed that the use of the accusative and infinitive after verbs of communication was unproductive and mainly limited to formal contexts. ${ }^{55}$ This is true to some extent: in our corpus, the accusative and infinitive mainly occurs in the semi-formulaic phrase $\dot{\alpha} \xi \mid \hat{\omega} / \alpha i \tau 0 \hat{\nu} \mu \alpha \mathrm{l} / \dot{\varepsilon} \rho \omega \tau \hat{\omega} / \pi \alpha \rho \alpha x \alpha \lambda \hat{\omega} \sigma \varepsilon$ $+(\text { active })^{56}$ aorist infinitive "I ask you to V", which accounts for $68 \%$ of the examples, and mainly occurs in formal documents (petitions). 57 This being said, it should be stressed that even in the Byzantine period the accusative and infinitive is used in non-formulaic contexts too, albeit to a limited extent. ${ }^{58}$

51 Contrast with example (7). For a similar example, see e.g. P.Brem.64, ll. 4-6 (II AD).

52 See e.g. P.Mil.Vogl.1.24, ll. 39-40 (117 AD); P.Flor.2.275, ll. 20-22 (III AD); PSI.12.126o, ll. 12-13 (III AD). There is also an example after the verb $\lambda \alpha \lambda \varepsilon^{\prime} \omega$ "I chatter": P.Sarap.85, 1. 10 (II AD).

53 Cf. Bentein (2015b:110-112).

54 For some examples, see e.g. P.Brem.37, l. 16 (II AD); sB.5.7558, ll. 18-19 (172/173AD?); P.Cair. Masp.1.67003, ll. 14-15 (567 AD).

55 See further $\$$ 4.1.

56 Alternatively, the passive aorist is used (typically with omission of the addressee). See e.g. SB.10.10244, l. 6 (50 AD); P.Oxy.41.2959, ll. 5-6 (99AD); P.Giss.82, l. 19 (117 AD); P.Apoll.50, ll. $3-4(703-715 \mathrm{AD})$.

57 For some examples, see e.g. BGU.16.2604, l. 12 (7 BC); BGU.16.2613, ll. 5-6 (15/14 BC); P.Graux. 2.9, l. 20 (33 AD); SB.18.13747, l. 13 (214-217 AD); BGU.2.417, ll. 2-4 (II/III AD).

$5^{8}$ For some examples, see e.g. P.Oxy.16.1868, ll. $3^{-4}$ (VI/VII AD); P.Lond.4.1345, ll. 30-35 (710 AD); P.Apoll.69, 1. 7 (703-715 AD). 
TABLE 6 Complementation after verbs of

communication (diachronic)

ő $\iota+$ ind. ACI ACP

\begin{tabular}{lrrr}
\hline MPG (I-III AD) & 99 & 176 & 5 \\
LPG (IV-VI AD) & 64 & 124 & 5 \\
EBG (VII-VIII AD) & 13 & 13 & NA \\
\hline
\end{tabular}

Table 6 shows that there are no more examples of the accusative and participle in the Byzantine period. The last examples date to the sixth century, and are

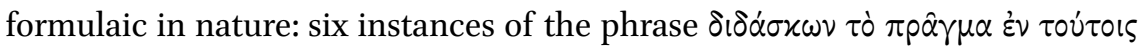
है'xov "informing that the matter is so" occur in the archive of Dioscorus. ${ }^{59}$

\subsection{Interim conclusion}

We can now make some interim conclusions. First, in terms of frequency, the accusative and infinitive is most often attested, much more so than ö $\tau$ l with the indicative and especially the accusative and participle. However, the high frequency of the accusative and infinitive is, at least partly, due to its appearance in formulaic phrases; moreover, after the fourth century AD it tends to be used much less frequently, and even disappears as a complementation pattern after verbs of perception and mental state. Second, in terms of factivity, we can say that there are, indeed, signs of the weakening of the relationship between specific complementation patterns and factivity or non-factivity. As shown in Figure 2, each of the three complementation patterns under discussion is used in non-classical contexts, for example, the accusative and infinitive after verbs of mental state such as $\gamma(v \omega \dot{\omega} \sigma \kappa \omega$ "I know", the accusative and participle after psychological verbs such as $\pi \rho 0 \sigma \delta 0 x \alpha$ ' $\omega$ "I expect", and ö $\tau$ เ with the indicative after verbs of communication such as $\varphi \eta \mu$ ' "I say". This being said, there is still a strong relationship between the accusative and infinitive and non-factivity: this is the only complementation pattern after causative verbs and verbs of ordering, and it triggers a different construal of verbs of communication.

59 See P.Cair.Masp.1.67008, l. 9 (ca. 522 AD?); P.Cair.Masp.1.67002, 1, l. 9 (567 AD); P.Cair.Masp. 1.67003, ll. 14-15 (567 AD); P.Lond.5.1677, ll. 10-11 (566-567 AD); P.Cair.Masp. 1.670o9, ll. 6-7 (ca. 567-570 AD); P.Lond. 5 1674, ll. 5-6 (ca. 570 AD). 
Causative verbs /

Psychological verbs

Verbs of perception /

verbs of ordering

mental state

Verbs of communication

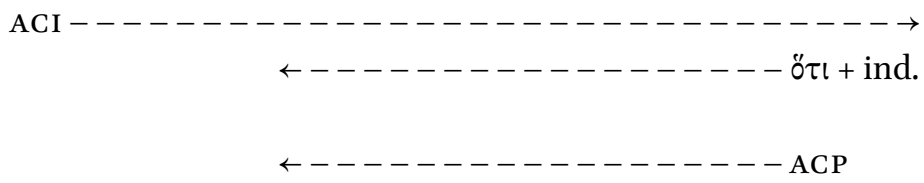

FIGURE 2 Extensions of complementation patterns

\section{$4 \quad$ Towards a new pragmatic opposition?}

In the second part of this article, I would like to take a different angle towards the distribution of our three complementation patterns, that is, starting from the social context in which they are used. As mentioned in the introduction, such a perspective is not entirely novel: previous studies by Hult (1990), Kavčič (2005), James (2008) and Sampanis (2011) have made reference to the notion of 'register'. Most of these studies are based on literary texts, however. Documentary texts allow us to go one step further, and look at the social dimensions that are behind registers in somewhat greater detail.

At present, there is no generally accepted theory concerning the relationship between language and social context. One linguistic framework which has done considerable effort to embed linguistic analysis within its social context, and which I will follow here, is the Systemic Functional one. ${ }^{60}$ This theory poses the existence of three major 'vectors of context', which are called 'field' (referring to the nature of the social activity, e.g., science), 'tenor' (referring to the interactants and their relationships, e.g., close friends), and 'mode' (referring to the medium or mode of the language activity, e.g., written vs. spoken communication).

Each of these three vectors can be further subdivided: for the tenor vector, on which I will concentrate here, ${ }^{61}$ Hasan (e.g. 1995, 1999) has proposed to

\footnotetext{
6o See e.g. Halliday \& Matthiesen (2014).

61 Since the mode vector remains constant and the field vector has relatively little impact on complementation.
} 
distinguish between 'social distance', 'agentive role' and 'social status'. In what follows, I will relate each of these three tenor-subvectors to our complementation patterns.

\subsection{Social distance}

Social distance ${ }^{62}$ is a well-known sociolinguistic variable; among others, it plays a prominent role in Brown \& Levinson's Politeness Theory (1987), and the notions of 'convergence' and 'divergence' that are used in Speech Accommodation Theory ${ }^{63}$ can be seen as personal distance vs. shortening of personal distance. Hudson proposes the following definition:

[Social distance] represents the distance between the speaker and the hearer and is, in effect, the degree of familiarity and solidarity they share as represented through in-group or out-group membership. This is reflective of the degree to which the two interactants identify with each other or share some affiliation and solidarity.

2001:284

Since such a degree of familiarity and solidarity is somewhat hard to measure in our texts, ${ }^{64}$ I propose to relate social distance to formality. ${ }^{65}$ Evidently, there is not a one-to-one correspondence between the two notions, since social distance is a property of interactants, and formality a property of texts (and situations). However, there is a clear connection between the two, as noted by Hasan (1973:242): '[social distance] is the factor which underlies the distinctions made on the axis of formality-familiarity'. Maximal social distance typically corresponds to high formality, and minimal social distance to low formality.

When it comes to documentary papyri, formality is a well-known notion: a distinction is often made between 'official' (formal) documents such as petitions, contracts and official letters, versus 'non-official' (informal) documents such as private and business letters. The importance of this distinction has been commented upon on various occasions: Lee (1985) and Bentein (2015a), for example, have explored its impact on particle-usage. When it comes to complementation, James (2008:54) has argued that 'in general there was an association of the participle, the infinitive, and the finite clause with particular types

62 Also called 'communicative' distance, see e.g. Peng (1974).

63 E.g. Giles (1980).

64 Some sociolinguistic studies have specified social distance by making a threefold distinction between 'strangers', 'friends', and 'intimates' (e.g., Wolfson 1988).

65 For further discussion of this notion, see Heylighen \& Dewaele (1999). 
TABLE $7^{66}$ Complementation in terms of social distance ( formality $)^{67}$

\begin{tabular}{lccccccc}
\hline & Documents & Lines & ő $\tau+$ ind. & ACI & $\begin{array}{c}\text { ACI } \\
\text { (form) }\end{array}$ & $\begin{array}{c}\text { ACI } \\
\text { (non-form) }\end{array}$ & ACP \\
\hline Formal & 783 & 15000 & 5.20 & 38.07 & 15.80 & 22.27 & 4.13 \\
Informal & 819 & 13608 & 23.59 & 54.09 & 39.17 & 14.92 & 1.54 \\
\hline
\end{tabular}

(Instances per 1000 lines)

of document'. To be more specific, he has argued that with verbs of perception/cognition and declaration, the accusative and infinitive was largely confined to 'bureaucratic' contexts (2008:57, 108), whereas ö $\tau \iota$ with the indicative increasingly became the standard in all sorts of documents (2008:104), mostly being used in personal and business letters (James 2001/2005:156). When it comes to the accusative and participle, James (2008:237) argues for an intermediate position, observing that 'the complementary participle was retained across the continuum of registers. It is attested (although not in the nominative) with verbs of perception and cognition in various text types, including personal letters'.

For an overview of the distribution of these three complementation patterns in our corpus, consider Table 7 .

This table shows that there is, indeed, a noticeable difference in usage between formal and informal documents when it comes to ö $\tau$ ı with the indicative: this complementation pattern is much less common in formal texts than it is in informal ones (with 5.20 vs. 23.59 instances per 1000 lines). Table 8 shows that the distribution of ö $\tau$ เ with the indicative in terms of verb class is more or less similar in both types of texts. However, the non-classical extensions of the pattern after non-factive psychological verbs and verbs of communication almost all occur in informal texts, ${ }^{68}$ with formal texts sticking closer to the Classical norm. ${ }^{69}$

66 I did not add diachronic information to the tables in this part of the article since that would over-complicate the already extensive tables.

67 In this and other tables, 'form' stands for formulaic; 'non-form' for non-formulaic.

68 For some examples, see e.g. P.Merton.2.63, ll. 12-13 (58 AD); B GU.1.248, l. 29 (ca. 75-76 AD); P.Brem.53, ll. 38-39 (114AD); P.Oxy.16.1940, l. 3 (vi/viI AD) (psychological verbs); P.Mich. 8.486, ll. 14-15 (II AD); P.Sarap.85, ll. 10-12 (II AD); P.Flor.2.275, ll. 20-22 (III AD); PSI.12.126o, ll. 12-14 (III AD) (verbs of communication).

69 One exception being P.Oxy.16.1829, ll. 7-9 \& 17-21 (ca. 577-583AD). 
TABLE 8 Complementation in terms of social distance (formality) and verb class

\begin{tabular}{|c|c|c|c|c|c|}
\hline & ö $\tau \iota+$ ind. & ACI & $\begin{array}{c}\text { ACI } \\
\text { (form) }\end{array}$ & $\begin{array}{c}\text { ACI } \\
\text { (non-form) }\end{array}$ & ACP \\
\hline Formal & 78 & 571 & 237 & 334 & 62 \\
\hline Causative verbs & NA & $78(13 \%)$ & o & 78 & NA \\
\hline Verbs of ordering & NA & $109(18 \%)$ & o & 109 & NA \\
\hline Verbs of perception & $11(14 \%)$ & $21(4 \%)$ & o & 21 & $41(66 \%)$ \\
\hline Verbs of mental state & $27(35 \%)$ & $13(2 \%)$ & 3 & 10 & $6(10 \%)$ \\
\hline Psychologicalverbs & $6(8 \%)$ & $117(20 \%)$ & 55 & 62 & $2(3 \%)$ \\
\hline Communicative verbs & $33(43 \%)$ & $233(39 \%)$ & 179 & 54 & $12(19 \%)$ \\
\hline Informal & 321 & 736 & 533 & 203 & 21 \\
\hline Causative verbs & NA & $70(9 \%)$ & o & 70 & NA \\
\hline Verbs of ordering & NA & $29(4 \%)$ & o & 29 & NA \\
\hline Verbs of perception & $41(13 \%)$ & $12(2 \%)$ & o & 12 & $9(43 \%)$ \\
\hline Verbs of mental state & $107(33 \%)$ & $23(3 \%)$ & 18 & 5 & $7(33 \%)$ \\
\hline Psychologicalverbs & $32(10 \%)$ & $5^{26}(70 \%)$ & 474 & $5^{2}$ & $4(6 \%)$ \\
\hline Communicative verbs & $140(44 \%)$ & $76(10 \%)$ & 41 & 35 & $1(5 \%)$ \\
\hline
\end{tabular}

The accusative and infinitive is common in both formal and informal texts, ${ }^{70}$ but if we look at the non-formulaic uses, we see the reverse distribution of ö $\tau$ เ with the indicative: the (non-formulaic) accusative and infinitive is more common in formal texts. To some extent, this is due to the fact that there are more examples after verbs of ordering, as shown in Table 8. However, the accusative and infinitive is also used quite frequently in other non-formulaic contexts: among others, several instances can be found after verbs of perception and mental state, ${ }^{71}$ that is, where the pattern has been extended from its Classical usage. $^{72}$

The accusative and participle, too, is more common in formal texts. Table 8 shows that the pattern is particularly frequently used after verbs of perception,

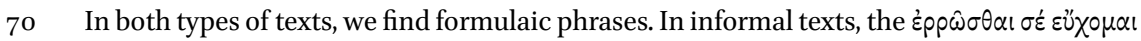
"I pray that you are well"-formula is most common, whereas in formal texts the $\dot{\alpha} \xi \hat{\omega} \sigma \varepsilon+$ aorist infinitive "I ask you to v"-formula.

71 Until the fourth century AD, that is.

72 For some examples, see e.g. P.Berl.Zill.3, ll. 8-9 (177-180AD); P.Mich.6.423, l. 11 (197AD); P.Sakaon.39, ll. 11-15 (318AD) (verbs of perception); P.Sakaon.46, ll. 10-11 (342 AD) (verbs of mental state). 
with 41 instances. It is also more frequently used after communicative verbs, with 12 instances. Non-classical extensions of the accusative and participle, after psychological verbs and verbs of communication such as $\lambda \dot{\varepsilon} \gamma \omega \omega$, can only be found in informal texts. ${ }^{73}$

\subsection{Agentive role}

Agentive role refers to "[the] relation between the speaker and the addressee from the point of view of the action they are performing. ${ }^{74}$ Similarly to social distance, agentive role ${ }^{75}$ is defined with reference to the specific communicative situation the interactants are involved in, as noted by Hasan (1973:242): 'only that role which is relevant to the discourse, irrespective of others that the speaker is capable of assuming on other occasions of verbal interaction involving the self-same persons'. Some modern examples of such socially positioned roles are supervisor — student, friend - friend, mother — son, vendor — customer, etc. Every person performs a multiplicity of these roles, which, combined, define a person's social identity.

In documentary papyri, too, a great variety of agentive roles can be observed: a brother writing to his brother, a husband to his wife, a servant to his master, a citizen to an official, an employer to his employee, a higher official to a lower official, etc. We can divide these agentive roles into three larger types: ${ }^{76}$ (i) an equal (writing to an equal); (ii) an unequal (writing to an unequal); ${ }^{77}$ (iii) a family member ${ }^{78}$ (writing to a family member). In work on formulaic phrases, terms of address and honorific epithets in documentary papyri, ${ }^{79}$ the relevance of this dimension has, occasionally, been mentioned. White (1981:93), for example, observes that 'regarding the family terms, "brother" and "sister" are

73 See e.g. P.Flor.2.127, ll. 2-3 (256AD); P.Bingen.121, ll. 15-16 (IV/VAD); P.Oxy.48.3409, ll. 910 (IVAD) (psychological verbs); P.Giss.Apoll.22, l. 6 (116-120AD) (verbs of communication).

74 Hasan (2004:34).

75 The concept of 'agentive role' is related to, but not identical with, the more familiar concept of 'social role'. For a discussion of participant roles within the more general social role system, see Hasan (1973:246-248).

76 Cf. Bentein (2015a:728).

77 This can be further subdivided into (a) a superordinate (writing to a subordinate), and (b) a subordinate (writing to a superordinate).

$7_{8}$ This agentive role can, on occasion, be hard to determine, since Roman and Byzantine authors were quite prone to use terms such as $\alpha \dot{\delta} \varepsilon \lambda \varphi \varsigma^{\varsigma}$ "brother" or $\pi \alpha \tau \eta \dot{\rho}$ "father", without referring to their actual brother or father (see further Dickey 2004). Working with archives, however, has the advantage that a lot of contextual information is known.

See e.g. Mullins (1962); Dickey (1996); Nachtergaele (2015). 


\begin{tabular}{|c|c|c|c|c|c|c|c|}
\hline & Documents & Lines & ö $\tau \iota+$ ind. & ACI & $\begin{array}{c}\text { ACI } \\
\text { (form) }\end{array}$ & $\begin{array}{c}\text { ACI } \\
\text { (non-form) }\end{array}$ & ACP \\
\hline Equal & 302 & 6167 & 20.43 & $53 \cdot 5^{1}$ & 31.62 & 20.76 & 2.43 \\
\hline Unequal & 874 & 17747 & $5 \cdot 97$ & 40.06 & 20.12 & $23 \cdot 38$ & $3 \cdot 32$ \\
\hline Superordinate & 363 & 5447 & $7 \cdot 53$ & 46.45 & 24.60 & 22.21 & 3.86 \\
\hline Subordinate & 533 & 12300 & 5.28 & 37.24 & 18.13 & 19.02 & 3.17 \\
\hline Family & 130 & 3118 & 36.24 & $49 \cdot 71$ & $37 \cdot 5^{2}$ & 11.55 & 0.96 \\
\hline
\end{tabular}

(Instances per 1000 lines)

often employed to express the friendship and equality of the correspondents, whether or not they are actually family members'.

The relationship between these generic agentive roles and the use of our complementation patterns can be observed in Table 9.

This table shows that, again, for ö $\tau$ เ with the indicative there are significant differences: equals and especially family members ${ }^{80}$ writing to each other are most likely to use this complementation pattern (with 20.43 and 36.24 instances per 1000 lines). When there is a hierarchical relationship between the interactants, ö $\tau$ เ with the indicative is much less likely to be used, especially when a subordinate is writing to his superordinate (with only 5.28 instances per 1000 lines). ${ }^{81}$ Table 10 shows that the distribution of ö $\tau$ เ with the indicative in terms of verb class is quite similar across our three different agentive categories. Non-classical extensions tend to occur ${ }^{82}$ when an equal writes to an equal, ${ }^{83}$ or a family member to a family member. ${ }^{84}$

8o For some examples, see e.g. P.Mich.3.201, ll. 16-17 (99AD); BGU.2.417, ll. 21-22 \& 25-26 (II/III AD); P.Mich.3.216, ll. 13-14 \& 32-33 (297 AD).

81 For some exceptional instances, see e.g. SB.5.7558, ll. 37-38 (172/173AD?); P.Flor.2.275, ll. 2022 (III AD); P.Abinn.28, ll. 17-18 (342-351AD); BGU.3.798, ll. 4-5 (IV-VII AD); P.Apoll.42, l. 3 (703-715AD).

82 For some exceptions, see e.g. P.Oxy.16.1854, ll. 2-3 (VI/VII AD) (superordinate); P.Flor.2.275, ll. 20-22 (III AD) (subordinate).

83 See e.g. BGU.1.248, l. 29 (ca. 75-76 AD); P.Michael.15, l. 6 (I/II AD); P.Brem.53, ll. 38-39 (114AD); P.Apoll.37, l. 6 (ca. 708-709AD) (psychological verbs); P.Mich.8.486, ll. 14-15 (II AD); P.Petaus.29, l. 8 (II AD) (verbs of communication).

84 See e.g. BGU.16.266o, ll. 12-14 (1AD) (psychological verbs); P.Sarap.85, ll. 10-12 (II AD) (verbs of communication). 
TABLE 10 Distribution of complementation patterns in terms of agentive role

\begin{tabular}{|c|c|c|c|c|c|}
\hline & ö $\tau \iota$ + ind. & ACI & $\begin{array}{c}\text { ACI } \\
\text { (form) }\end{array}$ & $\begin{array}{c}\text { ACI } \\
\text { (non-form) }\end{array}$ & ACP \\
\hline Equal & 126 & 323 & 195 & 128 & 15 \\
\hline Causative verbs & NA & $32(10 \%)$ & NA & 32 & NA \\
\hline Verbs of ordering & NA & $22(7 \%)$ & NA & 22 & NA \\
\hline Verbs of perception & $16(13 \%)$ & $10(3 \%)$ & NA & 10 & $7(47 \%)$ \\
\hline Verbs of mental state & $34(27 \%)$ & $8(2 \%)$ & 6 & 2 & $5(33 \%)$ \\
\hline Psychological verbs & $14(11 \%)$ & $209(65 \%)$ & 172 & 37 & $2(13 \%)$ \\
\hline Communicative verbs & $62(49 \%)$ & $42(13 \%)$ & 17 & 25 & $1(7 \%)$ \\
\hline Unequal & 106 & 713 & 357 & $35^{6}$ & 59 \\
\hline Causative verbs & NA & $90(13 \%)$ & NA & 90 & NA \\
\hline Verbs of ordering & NA & $102(14 \%)$ & NA & 102 & NA \\
\hline Verbs of perception & $17(16 \%)$ & $31(4 \%)$ & NA & 31 & $41(68 \%)$ \\
\hline Verbs of mental state & $36(34 \%)$ & $18(3 \%)$ & 6 & 12 & $3(5 \%)$ \\
\hline Psychological verbs & $10(9 \%)$ & $241(34 \%)$ & 175 & 66 & $3(5 \%)$ \\
\hline Communicative verbs & $43(40 \%)$ & $231(32 \%)$ & 176 & 55 & $12(20 \%)$ \\
\hline Family & 113 & 153 & 117 & 36 & 3 \\
\hline Causative verbs & NA & $12(8 \%)$ & NA & 12 & NA \\
\hline Verbs of ordering & NA & $2(1 \%)$ & NA & 2 & NA \\
\hline Verbs of perception & $12(11 \%)$ & $1(1 \%)$ & NA & 1 & NA \\
\hline Verbs of mental state & $50(44 \%)$ & $5(3 \%)$ & 5 & o & $3(100 \%)$ \\
\hline Psychological verbs & $7(6 \%)$ & $117(76 \%)$ & 104 & 13 & NA \\
\hline Communicative verbs & $44(39 \%)$ & $16(10 \%)$ & 8 & 8 & NA \\
\hline
\end{tabular}

As for the non-formulaic uses of the accusative and infinitive, we again see the reverse distribution: family members tend to use the pattern less frequently, but equals, superordinates and subordinates make more frequent use of it (with over 20 instances per 1000 lines). Extensions of the accusative and infinitive, after verbs of perception and mental state, are rarely found when a family member writes to a family member.

As for the accusative and participle, Table 9 shows that family members are very unlikely to use this pattern when writing to each other (with less than one instance per 1000 lines).${ }^{85}$ Unequals, - superordinates writing to subordinates

\footnotetext{
85 For some exceptional examples, see BGU.16.2616, ll. 9-10 (13 BC); P.Mich.8.477, l. 20 (II AD).
} 
in particular,- - use the pattern most frequently (with 3.86 instances per 1000 lines), especially after verbs of perception, as Table 10 shows. Extensions of the accusative and participle, after psychological verbs and communicative verbs such as $\lambda \varepsilon^{\prime} \gamma \omega$, can be found both with equals ${ }^{86}$ and unequals. ${ }^{87}$

\subsection{Social status}

Social status is arguably the most complex of the three contextual vectors that I am analysing: it can be further subdivided into factors such as age, gender, domicile, education, ethnicity, occupation, wealth, etc. As a parameter, social status is also somewhat different from social distance and agentive role, in that it pertains to stable characteristics of the interactants.

Social status (more specifically 'social class'88) was a key notion in early sociolinguistic work by scholars such as Labov (1966) and Bernstein (1971). Recently, it has made a comeback (for English, at least) in articles by Ash (2002), Mallinson (2007) and Kerswill (2007), among others, in which an argument is made for more interdisciplinary collaboration between (socio-)linguistics and recent developments in sociology. When it comes to Greek documentary papyri, studies have mostly focused on the relationship between social status and forms of address/honorific epithets. ${ }^{89}$ Recently, I have argued for the importance of the social status of the addressee when it comes to the use of inferential particles in Greek petitions (Bentein 2016).

The social classes that are typically referred to when it comes to Roman Egypt are based on ethnicity, whereby a distinction is made between Roman citizens, the citizens of the Greek cities of Egypt, and Egyptians. ${ }^{90}$ This classification has the disadvantage, however, that it is not applicable to Byzantine Egypt, and that it is difficult to apply to our corpus. I have therefore proposed to focus on occupation (Bentein 2015a), an element that also plays a key role in most sociolinguistic works on social status (class), ${ }^{91}$ proposing a number of very general 'occupational groups'. In this article, I largely follow this categorisation.

86 See e.g. P.Bingen.121, ll. 15-16 (IV/VAD); P.Oxy.48.3409, ll. 9-10 (IVAD) (psychological verbs); P.Giss.Apoll.22, l. 6 (116-120AD) (verbs of communication).

87 See e.g. P.Flor.2.127, ll. 2-3 (266 AD) (psychological verbs).

88 Social class is somewhat more specific than social status, focusing specifically on economic elements. For a general definition, see Ash (2002:402): 'here social class is defined as "an individual's life chances stated in terms of his relation to the production and acquisition of goods and services"'

89 See e.g. Hornickel (1930).

9o See e.g. Vandorpe (2012).

91 Compare Ash (2002:419): 'if social class is determined by a combination of features, the 
TABLE 11 Distribution of complementation patterns in terms of social distance addressee 92

\begin{tabular}{|c|c|c|c|c|c|c|c|}
\hline & Documents & Lines & ö $\tau \iota+$ ind. & ACI & $\begin{array}{c}\text { ACI } \\
\text { (form) }\end{array}$ & $\begin{array}{c}\text { ACI } \\
\text { (non-form) }\end{array}$ & $\mathbf{A C P}$ \\
\hline Higher official & 133 & 3620 & 4.97 & $5^{0.83}$ & 17.68 & 29.01 & 6.08 \\
\hline $\begin{array}{l}\text { Liberal } \\
\quad \text { professions }\end{array}$ & 35 & 5461 & 8.61 & $5^{6.03}$ & 41.20 & 14.83 & 0.73 \\
\hline Landowner & 46 & 872 & 20.64 & 40.14 & 22.94 & 17.20 & NA \\
\hline Local official & 176 & 3006 & $9 \cdot 31$ & $55 \cdot 5^{6}$ & 24.62 & 25.62 & $3 \cdot 99$ \\
\hline Mid-level official & 414 & 8030 & $5 \cdot 73$ & 32.13 & $15 \cdot 57$ & 16.31 & $4 \cdot 36$ \\
\hline Military & 93 & 2225 & 31.01 & $5^{0.79}$ & 32.36 & 18.43 & 3.60 \\
\hline $\begin{array}{l}\text { Ordinary } \\
\text { commoner }\end{array}$ & 13 & 205 & $19 \cdot 5^{1}$ & 34.15 & 29.27 & 4.88 & NA \\
\hline Ecclesiastic & $5^{8}$ & 1249 & 26.42 & 40.03 & 24.02 & 16.01 & 0.80 \\
\hline
\end{tabular}

(Instances per 1000 lines)

The relationship between the occupational group of the addressee and our complementation patterns is shown in Table 11.

With regard to $0 ँ \tau \iota$ with the indicative, this table shows that the complementation pattern was avoided when all sorts of officials are addressed, especially mid-level and higher officials (with respectively 4.97 and 5.73 instances per 1000 lines). For other occupational groups, such as landowners, ecclesiastics, and people from the military, this complementation pattern tends to be used much more often. Table 12 shows that the distribution of ö $\tau$ with the indicative in terms of verb class is similar across all occupational groups: the pattern is most often used after verbs of mental state and communicative verbs. The extension of o" $\tau$ เ with the indicative after non-factive psychological verbs and verbs of communication can, for the most part, ${ }^{93}$ be attributed to occupational groups other than officials.

single indicator that accounts for by far the greatest portion of the variance is occupation. Some researchers use occupation alone as a determiner of social class, and it is hard to imagine a composite index that excludes occupation.'

92 I have not included 'actors and athletes' and 'craftsmen and tradesmen' (cf. Bentein 2015a) because there were not enough texts for these groups.

93 For some exceptions, see P.Oxy.16.1829, ll. 7-9 \& 17-21 (ca. 577-583AD); P.Apoll.37, l. 6 (ca. 708-709AD). 
The distribution of the non-formulaic uses of the accusative and infinitive is not entirely opposite, as we have seen with our other social variables: it is quite noticeable, however, that most instances are attested with local and especially higher officials (with over twenty instances per 1000 lines). ${ }^{94}$ As Table 12 shows, the accusative and infinitive is frequently attested with all verb classes when officials are addressed. There are also several examples after verbs of mental state and perception, which can be considered extensions of the Classical usage. ${ }^{95}$ Such extensions are also attested with other occupational groups, but much less frequently. When these occupational groups are addressed, the (non-formulaic) accusative and infinitive is used much less often. For ordinary commoners, there is only a single instance. ${ }^{96}$

The accusative and participle does show a more or less opposite distribution with ö $\tau$ เ with the indicative: the pattern is mostly used for officials, ${ }^{97}$ particularly higher and mid-level officials (with 6.08 and 4.36 instances per 1000 lines respectively). Table 12 shows that the distribution of the instances is much more balanced than is the case for other occupational groups: instances can be found after verbs of perception/mental state, psychological verbs and communicative verbs. The use of the accusative and participle after psychological verbs can be considered an extension, motivated by the wish to achieve a pragmatic effect. ${ }^{98}$ Some examples of this extension are also attested with liberal professions and ecclesiastics. ${ }^{99}$

94 For mid-level officials, fewer instances of the accusative and infinitive (both formulaic and non-formulaic) are attested in general.

95 For some examples, see e.g. P.Sakaon.46, ll. 10-11 (342 AD) (mental state verbs); P.Berl.Zill.3, ll. 8-9 (177-180AD); P.Mich.6.423, l. 11 (197AD); PSI.12.1248, ll. 39-40 (235AD) (verbs of perception).

$96 \quad$ See P.Oxy.38.2844, 1l. 9-10 (50-100 AD).

97 People from the military form an exception: when they are addressed, both ö $\tau$ เ with the indicative and the accusative and participle are relatively frequently used. This may be due to the fact that they form a relatively heterogeneous group.

98 See e.g. CPR.30.3, ll. 10-13 (ca. 643-644AD).

99 For some examples, see e.g. P.Flor.2.127, ll. 2-3 (256 AD); P.Oxy.48.3409, ll. 9-10 (IV AD); P.Bingen.121, ll. 15-16 (IV/VAD). 
TABLE 12 Distribution of complementation patterns in terms of social distance addressee and verb class

\begin{tabular}{|c|c|c|c|c|c|}
\hline & ö $\tau \iota+$ ind. & ACI & $\begin{array}{c}\text { ACI } \\
\text { (form) }\end{array}$ & $\begin{array}{c}\text { ACI } \\
\text { (non-form) }\end{array}$ & ACP \\
\hline Liberal professions & 47 & 306 & 225 & 81 & 4 \\
\hline Causative verbs & NA & $34(11 \%)$ & NA & 34 & NA \\
\hline Verbs of ordering & NA & $12(4 \%)$ & NA & 12 & NA \\
\hline Verbs of perception & $6(13 \%)$ & $5(2 \%)$ & NA & 5 & NA \\
\hline Verbs of mental state & $20(43 \%)$ & $3(1 \%)$ & 2 & 1 & $2(50 \%)$ \\
\hline Psychological verbs & $5(10 \%)$ & $229(75 \%)$ & 211 & 18 & $2(50 \%)$ \\
\hline Communicative verbs & $16(34 \%)$ & $23(7 \%)$ & 12 & 11 & NA \\
\hline Landowner & 18 & 35 & 20 & 15 & o \\
\hline Causative verbs & NA & $4(11 \%)$ & NA & 4 & NA \\
\hline Verbs of ordering & NA & $2(6 \%)$ & NA & 2 & NA \\
\hline Verbs of perception & $2(11 \%)$ & NA & NA & NA & NA \\
\hline Verbs of mental state & $6(33 \%)$ & $2(6 \%)$ & 2 & NA & NA \\
\hline Psychological verbs & $1(6 \%)$ & $18(51 \%)$ & 15 & 3 & NA \\
\hline Communicative verbs & $9(50 \%)$ & $9(26 \%)$ & 3 & 6 & NA \\
\hline Military & 69 & 113 & 72 & 41 & 8 \\
\hline Causative verbs & NA & $13(12 \%)$ & NA & 13 & NA \\
\hline Verbs of ordering & NA & $8(7 \%)$ & NA & 8 & NA \\
\hline Verbs of perception & $8(12 \%)$ & $2(2 \%)$ & NA & 2 & $2(25 \%)$ \\
\hline Verbs of mental state & $22(32 \%)$ & $3(3 \%)$ & 2 & 1 & $6(75 \%)$ \\
\hline Psychological verbs & $4(6 \%)$ & $73(64 \%)$ & 64 & 9 & NA \\
\hline Communicative verbs & $35(51 \%)$ & $14(12 \%)$ & 6 & 8 & NA \\
\hline Official & 92 & 576 & 263 & 313 & 65 \\
\hline Causative verbs & NA & $69(12 \%)$ & NA & 69 & NA \\
\hline Verbs of ordering & $\mathrm{NA}$ & $97(17 \%)$ & NA & 97 & NA \\
\hline Verbs of perception & $21(23 \%)$ & $20(3 \%)$ & NA & 20 & $40(61 \%)$ \\
\hline Verbs of mental state & $24(26 \%)$ & $16(3 \%)$ & 6 & 10 & $7(11 \%)$ \\
\hline Psychological verbs & $9(10 \%)$ & $168(29 \%)$ & 102 & 66 & $5(8 \%)$ \\
\hline Communicative verbs & $38(41 \%)$ & $206(36 \%)$ & 155 & $5^{1}$ & $13(20 \%)$ \\
\hline Ordinary commoner & 4 & 7 & 6 & 1 & o \\
\hline Causative verbs & NA & $1(14 \%)$ & NA & 1 & NA \\
\hline Verbs of ordering & NA & NA & NA & NA & NA \\
\hline Verbs of perception & $2(50 \%)$ & NA & NA & NA & NA \\
\hline Verbs of mental state & NA & NA & NA & NA & NA \\
\hline
\end{tabular}


TABLE 12 Distribution of complementation patterns (cont.)

\begin{tabular}{lccrrr}
\hline & ö $\tau$ + ind. & ACI & $\begin{array}{c}\text { ACI } \\
\text { (form) })\end{array}$ & $\begin{array}{c}\text { ACI } \\
\text { (non-form) }\end{array}$ & ACP \\
\hline Psychologicalverbs & NA & $5(72 \%)$ & 5 & NA & NA \\
Communicative verbs & $2(50 \%)$ & $1(14 \%)$ & 1 & NA & NA \\
Ecclesiastic & 33 & 50 & 30 & 20 & 1 \\
Causative verbs & NA & $6(12 \%)$ & NA & 6 & NA \\
Verbs of ordering & NA & $3(6 \%)$ & NA & 3 & NA \\
Verbs of perception & $2(6 \%)$ & NA & NA & NA & NA \\
Verbs of mental state & $8(24 \%)$ & $4(8 \%)$ & 2 & 2 & NA \\
Psychological verbs & $6(18 \%)$ & $29(58 \%)$ & 22 & 7 & $1(100 \%)$ \\
Communicative verbs & $17(52 \%)$ & $8(16 \%)$ & 6 & 2 & NA \\
\hline
\end{tabular}

5 Conclusion

To conclude, I have attempted to show that the progressive desystematisation of the participle and infinitive in Post-classical and Byzantine Greek brought with it a destablisation of the Classical complementation system, in particular the role of factivity. Our texts shows that the three complementation patterns under analysis, $\dot{\tau} \tau$ เ with the indicative, the accusative and infinitive, and the accusative and participle, start to be used in non-classical contexts: the accusative and infinitive can now also be found after verbs of mental state, ö $\tau$ เ with the indicative also after communicative verbs with a non-factive complement, and the accusative and participle after psychological verbs. This is not to say that factivity played no role whatsoever. To some extent at least, our complementation patterns still follow the Classical rules: after causative verbs and verbs of ordering, only the accusative and infinitive is attested.

I have argued that next to factivity, another pragmatic factor came to play a role ${ }^{100}$ when it comes to the distribution of complementation patterns, namely the social context in which they are used. As with factivity, this factor entails a pragmatic opposition between 0 $\tau \iota$ with the indicative and the accusative

100 This is not to say that it did not play any role in previous periods whatsoever. However, since the infinitive and participle (still) formed stable categories, there is less reason to suspect pragmatic distinctions of the kind we have encountered in this article. 
and infinitive: the former is used in informal contexts, by equals and family members, and is avoided when writing to officials; the latter, on the other hand, is used in formal contexts, by superordinates, subordinates, and also equals, and is used particularly when writing to officials. ${ }^{101}$ Contrary to what was the case in Classical times, the accusative and participle tends to side with the accusative and infinitive, rather than with ö $\tau$ with the indicative, showing a similar social distribution. ${ }^{102}$

The above-mentioned extensions of our complementation patterns can be related to our second pragmatic factor. Rather than that we are dealing with unconscious 'mistakes' confined to lower-register texts, we see that the Classical norm tends be overridden in specific contexts: the accusative and infinitive is mostly extended in higher social contexts (motivated by the wish to achieve a pragmatic effect), whereas ö $\tau$ เ with the indicative is typically extended in lower social contexts (motivated by a greater ease of use). From this point of view, at least, we can speak of a 'restructuring' of the complementation system, albeit a modest one.

\section{References}

Ash, Sharon. 2002. Social class. In Jack K. Chambers, Peter Trudgill \& Natalie SchillingEstes (eds.), The handbook of language variation and change, 402-422. Oxford: Blackwell.

Bentein, Klaas. 2015a. Particle-usage in documentary papyri (I-IV AD). An integrated, sociolinguistically-informed approach. Greek, Roman and Byzantine Studies 55(3). 721-753.

Bentein, Klaas. 2015b. Minor complementation patterns in Post-classical Greek (IVIAD). A socio-historical analysis of a corpus of documentary papyri. Symbolae Osloenses 89. 104-147.

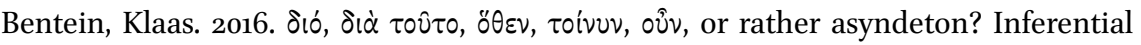
expressions and their social value in Greek official petitions (I-IV AD). Acta Classica 59. $23-51$.

Bernstein, Basil. 1971. Class, codes and control. London: Routledge.

101 It should be said that this opposition only goes for the non-formulaic uses of the accusative and infinitive: in formulaic phrases, the complementation pattern remains frequently used in all contexts.

102 Contrast with James (2008), who considers the accusative and participle to have had an intermediary position. 
Brown, Penelope \& Stephen C. Levinson. 1987. Politeness: Some universals in language usage. Cambridge: Cambridge University Press.

Cristofaro, Sonia. 1995. La complementazione frasale dopo verbi di "dire" e "pensare". In Pierluigi Cuzzolin (ed.), Studi di linguistica greca, 91-112. Milano: FrancoAngeli.

Cristofaro, Sonia. 1996. Aspetti sintattici e semantici delle frasi completive in greco antico. Firenze: Nuova Italia.

Cristofaro, Sonia. 2008. A constructionist approach to complementation: Evidence from Ancient Greek. Linguistics 46. 571-6o6.

Cristofaro, Sonia. 2012. Participial and infinitival complement sentences in Ancient Greek. In: Volker Gast \& Holger Diessel (eds.), Clause linkage in cross-linguistic perspective, 335-362. Berlin: de Gruyter.

De Boel, Gunnar. 1999. La concurrence entre l'infinitif et la subordonnée par ö $\pi \omega \varsigma / i v \alpha$ en attique classique et en grec neotestamentaire. In Bernard Jacquinod (ed.), Les completives en grec ancien, 265-276. Saint-Etienne: Publications de l'Université de Saint-Etienne.

Dickey, Eleanor. 1996. Greek forms of address:from Herodotus to Lucian. Oxford: Oxford University Press.

Dickey, Eleanor. 2004. Literal and extended use of kinship terms in documentary papyri. Mnemosyne 57(2). 131-176.

Giles, Howard. 1980. Accommodation theory: Some new directions. York papers in Linguistics 9. $105^{-136 .}$

Givón, Talmy. 2001. Syntax: An introduction. Amsterdam: Benjamins.

Halliday, Michael A.K. \& Christian M.I.M. Matthiessen. 2014 ${ }^{4}$. Halliday's introduction to Functional Grammar. London \& New York: Routledge.

Hasan, Ruqaiya. 1973. Code, register and social dialect. In Basil Bernstein (ed.), Class, codes and control: Applied studies towards a sociology of language, 253-292. London: Routledge.

Hasan, Ruqaiya. 1995. The conception of context in text. In Peter H. Fries \& Michael Gregory (eds.), Discourse in society: Systemic Functional perspectives, 183-283. Norwood: Ablex.

Hasan, Ruqaiya. 1999. Speaking with reference to context. In Mohsen Ghadessy (ed.), Text and context in Functional Linguistics: Systemic perspectives, 219-328. Amsterdam: Benjamins.

Hasan, Ruqaiya. 2004. Analysing discursive variation. In Lynne Young \& Claire Harrison (eds.), Systemic functional linguistics and critical discourse analysis studies in social

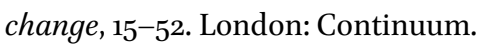

Heylighen, Francis \& Jean-Marc Dewaele. 1999. Formality of Language: definition, measurement and behavioral determinants. Internal Report, Center "Leo Apostel", Free University of Brussels. http://pespmci.vub.ac.be/papers/formality.pdf (October 20, 2014). 
Hornickel, Otto. 1930. Ehren- und Rangpradikate in den Papyrusurkunden: ein Beitrag zum romischen und byzantinischen Titelwesen. Borna: Noske.

Hudson, Thom. 2001. Indicators for pragmatic instruction: Some quantitative tools. In Kenneth R. Rose \& Gabriele Kasper (eds.), Pragmatics and language teaching, 283300. Cambridge: Cambridge University Press.

Hult, Karin. 1990. Syntactic variation in Greek of the 5th century A.D. Göteborg: Acta universitatis Gothoburgensis.

James, Patrick. 2001/2005. Participial complementation in the Roman and Byzantine

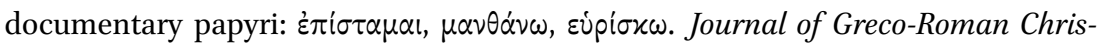
tianity and Judaism 2. 153-167.

James, Patrick. 2008. Complementary participles and infinitives with verbs of perception and declaration in the Roman and Byzantine documentary papyri. PhD Dissertation, Cambridge University.

Joseph, Brian D. $1987^{2}$. Greek. In Bernard Comrie (ed.), The world's major languages, 347-372. London: Croom Helm.

Kavčič, Jerneja. 2005. The syntax of the infinitive and the participle in Early Byzantine Greek. Ljubljana: University of Ljubljana.

Kerswill, Paul. 2007. Social class. In Carmen Llamas, Louise Mullany \& Peter Stockwell (eds.), The Routledge companion to sociolinguistics, 51-61. New York.

Labov, William. 1966. The social stratification of New York City. Washington (D.C.): Center for Applied Linguistics.

Lee, J.A.L. 1985. Some features of the speech of Jesus in Mark's Gospel. Novum Testamentum 27(1). 1-26.

Levin, Beth. 1993. English verb classes and alternations. Chicago: University of Chicago Press.

Luraghi, Silvia. 1999. The subject of complement clauses with the infinitive. In Bernard Jaquinod (ed.), Les complétives en grec ancien, 199-213. Saint-Etienne: Publications de l'Université de Saint-Etienne.

Lyons, John. 1977. Semantics. Cambridge: Cambridge University Press.

Mallinson, Christine. 2007. Social class, social status and stratification: Revisiting familiar concepts in sociolinguistics. University of Pennsylvania Working Papers in Linguistics 13. 149-163.

Mayser, Edwin. 1926. Grammatik der griechischen Papyri aus der Ptolemäerzeit, Band II.3: Satzlehre. Leizpig: Teubner.

Mihevc-Gabrovec, Erika. 1972. L' infinitif du passif avec les verba iubendi. Ziva Antika 22. 91-97.

Mullins, Terence Y. 1962. Petition as a literary form. Novum Testamentum 5. 46-54.

Nachtergaele, Delphine. 2015. The formulaic language of the Greek private papyrus letters. PhD dissertation, Ghent University.

Noonan, Michael. 2007[1985]. Complementation. In Timothy Shopen (ed.), Typology and syntactic description, vol. 2, 52-150. Cambridge: Cambridge University Press. 
Peng, Fred. 1974. Communicative distance. Language Sciences 31. 32-38.

Richards, Ernest R. 2004. Paul and the first-century letterwriting: secretaries, composition and collection. Downers Grove: InterVarsity press.

Rijksbaron, Albert. 2002. The syntax and semantics of the verb in Classical Greek. Amsterdam : Gieben.

Sampanis, Konstantinos. 2011. Parallel and 'antagonistic' complementation structures in the history of the Greek language. Wiener Linguistische Gazette 75. 112-125.

Smyth, Herbert W. 1984[1920]. Greek grammar. Harvard: Harvard University Press.

Vandorpe, Katelijn. 2009. Archives and dossiers. In Roger Bagnall (ed.), The Oxford handbook of papyrology, 216-255. Oxford: Oxford University press.

Vandorpe, Katelijn. 2012. Identity in Roman Egypt. In Christina Riggs (ed.), The Oxford Handbook of Roman Egypt, 260-276. Oxford: Oxford University Press.

White, John L. 1981. The Greek documentary letter tradition third century B.C.E. to third century C.E. Semeia 22. 89-106.

Wolfson, Nessa. 1988. The bulge: A theory of speech behaviour and social distance. In Jonathan Fine (ed.), Second language discourse: A textbook of current research, 21-38. Norwood: Ablex. 